\title{
Faktor - Faktor yang Mempengaruhi Literasi Keuangan: Studi Kasus UMKM Kota Tangerang Selatan
}

\author{
Baiq Fitri Arianti ${ }^{1 *)}$, Khoirunnisa Azzahra ${ }^{2}$ \\ ${ }^{1 * 22}$ Program Studi Akuntansi, Fakultas Ekonomi, Universitas Pamulang \\ Jl. Surya Kencana No. 1, Pamulang Tangerang Selatan Banten, 15417, Indonesia \\ E-mail:dosen00862@unpam.ac.id ${ }^{\left.1^{*}\right)}$
}

\begin{abstract}
ABSTRAK
Penelitian ini bertujuan dapat memberikan kontribusi bagi bidang manajemen keuangan terutama terkait keberlanjutan usaha dalam hal pengelolaan keuangan usaha melalui peningkatan literasi keuangan yang dapat dilihat dari pendapatan, investasi, perilaku keuangan, tingkat pendidikan dan pengalaman kerja. Jumlah sampel sebanyak 100 pelaku UMKM dengan metode simple random sampling. Sumber data yang digunakan berupa data primer dan data sekunder. Metode analisis data yang di gunakan yaitu regresi berganda dengan SPSS. Ditemukan hasil penelitian bahwa pendapatan, investasi, perilaku keuangan, tingkat pendidikan dan pengalaman kerja secara parsial memiliki pengaruh positif dan signifikan terhadap literasi keuangan. Dan secara simultan pendapatan, investasi, perilaku keuangan, tingkat pendidikan dan pengalaman kerja memiliki pengaruh signifikan terhadap tingkat literasi keuangan. Implikasi dalam penelitian ini adalah dapat memberikan informasi tentang pengelolaan keuangan yang baik sehingga akan membantu masyarakat terutama pelaku UMKM dalam perencanaan keuangan jangka pendek maupun jangka panjang serta memiliki pengetahuan dan wawasan yang lebih luas.
\end{abstract}

Kata kunci: Pendapatan; investasi; perilaku keuangan; tingkat pendidikan; pengalaman kerja

\begin{abstract}
This research aims to contribute to the field of financial management especially related to business sustainability in terms of business financial management through improved financial literacy which can be seen from income, investment, financial behavior, education level and work experience. The sample number of 100 MSME actors with simple random sampling method. The data source used is primary data and secondary data. The method of analyzing the data used is multiple regression with SPSS. It found that income, investment, financial behavior, education level and work experience as parsial have a positive and significant influence on financial literacy. And simultaneously income, investment, financial behavior, education level and work experience have a significant influence on financial literacy rates. The implication in this study is that it can provide information about good financial management so that it will help people, especially MSMEs, in short and longterm financial planning and have broader knowledge and insights.
\end{abstract}

Keywords: Income; investment; financial behavior; education level; work experience 


\section{PENDAHULUAN}

Era digitalisasi 4.0 menuju 5.0 pada sektor UMKM masih rendah di sebabkan kurangnya pemerintah untuk melakukan sosialisasi dan edukasi di kalangan usaha kecil mikro menengah sebagai upaya untuk membangkitkan pelaku usaha yang terdampak secara ekonomi terutama dari segi pendapatan akibat pandemic covid 19 dan pemerintah seharusnya melakukan sosialisasi dan edukasi secara merata kepada masyarakat Indonesia terkait layanan keuangan digital seperti pada penggunaan transaksi dalam berinvestasi, asuransi dan tabungan/pinjaman melalui kartu kredit, debit e-money ataupun menggunakan server kode QRIS. Usaha mikro kecil menengah ini paling banyak pelaku usaha di Indonesia yaitu sekitar 90\% namun pada umum nya kurang memiliki kemampuan dan pengetahuan serta keterampilan dalam mengelola keuangan pribadi nya. Di Tengah krisis moneter pada tahun 1998 dan sektor yang tetap bertahan adalah hanya sektor UMKM, peristiwa tersebut seolah olah terulang kembali dengan kondisi pandemic Covid 2019 saat ini bahwa terjadinya penurunan omzet penjualan seperti penjual makanan ringan dan sejenisnya, pedagang asongan atau kaki lima, restoran/warung makan hingga yang berjualan di pasar yang dapat menghambat aktivitas pelaku usaha cenderung semakin berkurang dan membuat pendapatan para pelaku usaha tersebut anjlok. Adanya kondisi seperti itu membuat mereka merasa kesulitan dalam menyeimbangkan arus kas termasuk dalam memenuhi kebutuhan produksi karena omzet yang di dapat tidak sesuai dengan harapan bahkan pelaku UMKM banyak yang merugi dan gulung tikar yang akan berdampak pada tingkat literasi keuangan. Menurut Victoria Simanungkalit selaku Deputi Bidang Produksi dan Pemasaran Kemenkop (2020) mengatakan bahwa ada empat permasalahan yang sering terjadi pada pelaku UMKM yaitu penurunan permintaan, pemasaran produk, akses bahan baku dan rendah nya SDM. Cara pemerintah menudukung UMKM agar tetap bertahan yaitu dengan memberikan intensif dan stimulus sebesar Rp. 123,4 triliun. Melihat dari jumlah data pelaku usaha dikota Tangerang Selatan pada tahun 2018 pada tabel 1.

Pada tabel 1 menggambarkan bahwa data jumlah binaan UMKM cukup baik di Tangerang Selatan tahun 2019 yaitu pada tahun 2018 sebanyak 23.085 dan paling banyak di dominasi oleh produk kuliner sekitar 60\%. UMKM sering juga menimbulkan beberapa kendala di dalam meningkatkan daya saing produk di pasar yaitu kurang nya akses permodalan dan akses produk pemasaran di mana pelaku usaha (UMKM) harus memahami dan mengetahui penggunaan dan pemanfaatan layanan jasa keuangan melalui digital atau internet sehingga pelaku usaha dapat meningkatkan daya saing produk nya. Disamping itu 
Tabel 1. Data Jumlah Binaan UMKM di Kota Tangerang Selatan Tahun 2018

\begin{tabular}{lcccccccc}
\hline Jenis UMKM & & \multicolumn{9}{c}{ Kecamatan } & \multicolumn{3}{c}{ Jumlah } \\
\hline & Ciputat & Ciptim & Pamulang & Pd.Aren & Setu & Serpong & Serpong \\
Kuliner & 1494 & 1705 & 842 & 973 & 486 & 2137 & 1230 & 8867 \\
Fashion & 119 & 85 & 65 & 152 & 36 & 291 & 45 & 793 \\
Sembako/Toko & 1132 & 825 & 709 & 1508 & 421 & 1623 & 1187 & 7405 \\
Aksesoris & 112 & 85 & 47 & 63 & 20 & 167 & 47 & 541 \\
Perikanan & 28 & 10 & 20 & 49 & 9 & 37 & 27 & 180 \\
Pertanian & 8 & 8 & 77 & 89 & 28 & 57 & 27 & 294 \\
Konveksi & 34 & 34 & 47 & 214 & 18 & 43 & 33 & 423 \\
Restoran & 102 & 61 & 25 & 117 & 31 & 135 & 100 & 571 \\
Konter/Hp & 197 & 80 & 140 & 131 & 62 & 174 & 139 & 923 \\
Jasa & 350 & 413 & 195 & 367 & 164 & 534 & 431 & 2454 \\
Furniture & 41 & 29 & 24 & 120 & 15 & 59 & 34 & 322 \\
Kreatif & 38 & 51 & 58 & 47 & 13 & 60 & 45 & 312 \\
Jumlah & 3655 & 3386 & 2249 & 3830 & 1303 & 5317 & 3345 & 23085 \\
UMKM & & & & & & & & \\
\hline Sw : & & & & & & &
\end{tabular}

Sumber : RPJMD Kota Tangsel, 2019

pula permasalahan yang terjadi terkait tingkat financial literacy pada pelaku usaha mikro kecil menengah dikota Tangerang Selatan dapat ditemukan bahwa pihak pelaku usaha dan dinas UMKM sama - sama belum mengetahui serta baru mendengar tentang literasi keuangan, pernyataan tersebut diperoleh dari hasil observasi awal dengan salah satu pegawai dinas koperasi dan UMKM di kota Tangsel yang mengatakan bahwa kurang memahami dan tidak memiliki pengetahuan mengenai literasi keuangan, hal ini di sebabkan bahwa kurangnya sosialisasi dan edukasi mengenai literasi keuangan oleh pihak OJK maupun pihak pemerintah terhadap pelaku usaha karena dinas koperasi dan UMKM lebih mendominasikan pada pendapatan pelaku usaha setiap bulannya padahal literasi keuangan juga sangat penting untuk diketahui dan dipahami bagi mereka supaya mereka lebih memahami dan mengetahui serta memiliki kemampuan mengelola keuangan dengan bijak dalam membuat pembukuan yang memisahkan antara dana operasional usaha dan keluarga serta kemampuan untuk menghitung biaya produk dengan tepat. Hal itu menyebabkan biaya produk per unit sebagai dasar penetapan harga jual per unit menjadi tidak tergambarkan dengan jelas. Disamping itu juga kendala yang dihadapi pelaku UMKM adalah pada persoalan pemasaran tentang tekhnologi digital dan potensi media sosial sebagai sarana promosi serta sulitnya akses permodalan seperti akses pinjaman dengan bunga rendah kepada pelaku UMKM. Selanjutnya, pemberian akses kredit yang mudah juga harus dibarengi dengan penetapan pajak yang murah bagi para UMKM yang memasarkan produknya secara digitalisasi dan bisa dilakukan dengan pemberian pinjaman tanpa bunga kepada sektor UKM ini. 
Determinan literasi keuangan di pengaruhi oleh faktor demografi dan sosiekonomi. Pemahaman pada demografi adalah sebuah gambaran tetang latar belakang seseorang sehingga dapat mempengaruhi literasi keuanganya, Yusnita \& Abdi (2018). Faktor - faktor yang dimaksud adalah pendapatan, investasi, perilaku keuangan, tingkat pendidikan dan pengalaman kerja. Misalkan pada faktor investasi, jika seorang individu tidak memiliki pengetahuan keuangan yang baik maka di khawatirkan banyaknya godaan untuk berperilaku konsumtif dan tertipu dengan investasi bodong, hal tersebut perlu di sadari bahwa masyarakat harus memiliki pengetahuan keuangan yang baik atau manajemen keuangan yang memadai agar penghasilan yang diperoleh tidak hanya digunakan untuk konsumsi melainkan untuk berinvestasi yang bermanfaat di masa depan.

Remund (2010) mengungkapkan bahwa literasi keuangan adalah seorang individu harus memahami arti pentinya konsep - konsep keuangan dan memiliki kapasitas dan kepercayaan diri dalam menangani dana pribadi yang tepat termasuk dalam pengambilan keputusan investasi dan perencanaan keuangan dalam jangka panjang maupun jangka pendek. Kemudian menurut Arianti (2020) mengatakan bahwa literasi keuangan dipengaruhi oleh faktor asuransi, investasi, tabungan (pinjaman) dan pengetahuan konsep keuangan. Artikel ini berkaitan dengan artikel Suryanto \& Rasmini (2018) mengungkapkan bahwa pendidikan dan pendapatan usaha memiliki pengaruh pada tingkat literasi keuangan. Artikel ini juga diungkapkan oleh Juris \& Raymond (2017) bahwa finansial pengetahuan berkorelasi positif dengan keuangan perilaku dan sikap, namun perilaku dan Sikap mengungkapkan bahwa tidak ada hubungan yang signifikan dikarenakan pelaku UMKM masih banyak yang memiliki tingkat keuangan pengetahuan, dan perilaku serta sikap yang rendah. Dan artikel Yusnita \& Abdi (2018) mengungkapkan bahwa tingkat income yang dapat mempengaruhi literasi keuangan. Selanjutnya artikel Anggraeni (2015) mengemukakan bahwa pelaku UMKM depok masih rendah nya literasi keuangan dikarenakan mereka belum pernah melakukan pencatatan laporan arus kas nya.

Artikel ini sangat penting untuk diteliti karena masih jarang yang meneliti terkait dengan faktor yang mempengaruhi tingkat literasi keuangan pada pelaku usaha dikota Tangerang Selatan. Maka dari itu penelitian ini perlu diteliti lebih dalam lagi supaya dapat memberikan kontribusi kepada pelaku usaha (UMKM) dalam memahami, mengetahui dan memiliki manajemen keuangan yang cukup karena dengan adanya pengelolaan keuangan yang baik akan membantu pelaku UMKM dalam membuat perencanaan keuangan jangka pendek maupun jangka panjang, sehingga diharapkan dengan menerapkan hal tersebut dapat membuat kesejahteraan dalam keuangannya. Dan kesulitan keuangan bukan hanya di 
sebabkan oleh rendah nya tingkat penghasilan tetapi di sebabkan kesalahan dalam melakukan manajemen keuangan, untuk itu di butuhkan literasi keuangan yang cukup.

Pada artikel ini terdapat rumusan masalah yaitu apakah pendapatan, investasi, perilaku keuangan, tingkat pendidikan dan pengalaman kerja memiliki pengaruh terhadap literasi keuangan. Tujuan dilakukan nya penelitian ini adalah untuk meningkatkan literasi keuangan dan membantu para pelaku usaha dalam memperbaiki pengelolaan keuangan usaha dengan memperkenalkan teknik pencatatan atau pembukuan usaha yang tepat kepada para pelaku usaha (UMKM) di kota Tangerang Selatan.

Penelitian mengenai tingkat literasi keuangan relevan dengan grand theory of planned behaviour (TPB). Teori tersebut diungkapkan oleh Ajzen (1991) mengemukakan bahwa sikap dan kepercayaan seseorang dapat mempengaruhi perilaku seorang individu dalam menerima atau menolak suatu keputusan. Teori ini juga menjelaskan adanya keterkaitan seorang individu memiliki niat dalam meningkatkan literasi keuangan bahwa semakin rendah pendapatan, investasi, perilaku keuangan, tingkat pendidikan, pengalaman kerja maka tingkat literasi keuangan mereka akan semakin rendah pula karena di sebabkan minim nya akses lembaga keuangan dan kurang nya pengetahuan keuangan terhadap sektor tersebut.

Artikel ini juga mencoba mengkaitkan teori atribusi dicetuskan pertama kali oleh Fritz Heider (1958). Dimana theory tersebut merupakan theory yang menerangkan tentang perilaku dan sikap seseorang. Teori ini dapat menghubungkan financial behavior seorang individu dalam memanajemen keuangan dengan baik. Teori atribusi tersebut mendukung penelitian ini karena penelitian ini dilakukan untuk mengetahui determinan dari literasi keuangan sebagai faktor - faktor yang mempengaruhi nya karena di dasarkan pada asumsi bahwa sikap dan perilaku sesorang individu di tentukan oleh keinginan individu sendiri.

Menurut Sabri (2011) mengungkapkan literasi keuangan merupakan pengetahuan dasar yang memahami mengelola keuangan dengan bijak dalam cara bagaimana menggunakan dana untuk belanja, asuransi, menabung, dan berinvestasi. Sedangkan artikel Bhusan \& Medury (2013) mengungkapkan literasi keuangan adalah kemampuan seorang individu dalam mendapatkan informasi dan mengambil keputusan yang tepat mengenai penggunaan dan pengelolaan keuangan peribadinya. Hal yang sama juga diungkapkan oleh Aribawa (2016), yang menyatakan bahwa literasi keuangan yang baik akan meningkatkan kinerja dan keberlanjutan UMKM. Literasi keuangan adalah kebutuhan saat ini karena pertumbuhan di pasar keuangan. Tetapi tingkat keuangan melek huruf tidak tinggi dan dilaporkan rendah dalam penelitian oleh banyak negara. Berdasarkan penelitian sebelumnya, saya mengamati berbagai faktor penting yaitu usia, pekerjaan, tingkat pendapatan, jenis keluarga, sikap serta 
prilaku keuangan terhadap literasi keuangan.

Income merupakan total pendapatan kotor seorang individu tahunan yang berasal dari upah, bisnis dan produk investasi (Arianti, 2020). Kemudian Lumintang (2013) menyatakan pendapatan adalah indikator untuk mengukur kesejahteraan dan tingkat keuangan pribadi. Semakin tinggi tingkat pendapatan seorang individu maka tingkat literasi keuangan orang tersebut semakin tinggi pula karena mereka memperoleh pemahaman pengetahuan keuangan dalam memanfaatkan keuangan dengan cara yang lebih baik, Mahdzan et al., (2013). Jadi, pendapatan dapat diartikan sebagai sebuah hasil yang di peroleh dari jerih payah seseorang dalam bekerja atau mempunyai usaha dan dinilai dengan tingkat atau nilai tertentu.

Investasi merupakan suatu pengorbanan yang dilakukan seorang indvidu dengan tujuan untuk mendapatkan manfaat yang lebih besar di masa yang akan datang (Dewi \& Purbawangsa, 2018). Jika seorang individu memiliki tingkat literasi keuangan yang cukup baik maka seorang individu juga dapat mengambil suatu keputusan berupa investasi, yang dimaksud dengan pengambilan keputusan investasi ini merupakan suatu proses untuk menyimpulkan serta membuat keputusan dari beberapa permasalah, membuat beberapa pilihan diantara dua atau lebih alternatif investasi atau bagian dari transformasi input menjadi output. Di dalam pengambilan keputusan investasi, seorang individu banyak di pengaruhi oleh perilaku keuangan dan literasi keuangan yang menjadi kebutuhan dasar bagi setiap orang agar terhindar dari permasalahan keuangan. Permasalahan keuangan timbul bukan hanya dilihat dari tingkat pendapatan saja namun dapat disebabkan dari kesalahan dalam mengelola keuangan misal nya tidak adanya perencanaan keuangan dan kesalahan dalam menggunakan kartu kredit serta banyak nya penipuan dalam kasus investasi bodong. Hal tersebut diakibatkan lemahnya literasi keuangan yang dimiliki.

Perilaku keuangan merupakan perilaku seorang individu dalam mengatur keuangan mereka dari sudut pandang psikologi dan kebiasaan individu atau berkaitan dengan bagaimana seorang individu memperlakukan, mengelola dan menggunakan sumber daya keuangan yang apa adanya (Susanti et al., 2017). Seorang individu yang memiliki perilaku keuangan akan bertanggung jawab atas penggunaa uang/dana yan dimilikinya seperti membuat anggaran pada setiap bulan nya, menghemat uang, mengontrol shopping, berinvestasi dan membayar utang tepat waktu. Karena perilaku keuangan ini memiliki beberapa indikator baik dari anggaran perencanaan keuangan yang dimiliki, menabung, asuransi, pension, berinvestasi, pengeluaran tidak terduga dan membayar cicilan kredit tepat waktu serta mengevaluasi manajemen keuangan pribadinya (Humaira \& Sagoro, 2018). 
Pendidikan sangat urgent dalam mempengaruhi literasi keuangan agar pelaku usaha (UMKM) dapat membentuk behavior yang melek financial. Konseptual alat ukur keuangan dalam membuat keputusan keuangan yang tepat sangat tergantung pada tingkat pendidikan seorang individu. Pendidikan tersebut sangat berdampak pada literasi keuangan karena dengan adanya pendidikan akan membentuk sikap, pengetahuan dan perilaku keuangan, (Sabri, 2011). Pendidikan diukur melalui aspek pendidikan formal maupun non formal yang di peroleh pelaku usaha. Orang yang memiliki pendidikan tinggi belum tentu memahami bagaimana memanfaatkan penggunaan layanan keuangan dan mencatat anggaran keuangan dengan baik begitu juga sebalik nya.

Menurut artikel Istiyati (2020) mengungkapkan bahwa pengalaman kerja merupakan sebagai suatu lama nya bekerja seorang individu agar menjadi pengalaman yang lebih baik yang dapat memberikan kesempatan dalam mengembangkan ketrampilan yang sangat berharga untuk bekal untuk masa depan. Sedangkan penelitian Irman dan Fadrul (2018) mengemukakan bahwa pengalaman kerja merupakan sebagai suatu kemampuan yang dimiliki seorang individu dalam menjalankan tugas dan tanggung jawabnya. Dengan adanya pengalaman kerja yang cukup lama maka seorang individu akan memiliki kemampuan yang lebih tinggi daripada seseorang yang tidak memiliki pengalaman kerja. Beberapa indikator dalam pengalaman kerja yaitu lama nya usaha, artinya lama waktu yang sudah dijalani pelaku usaha (UMKM) dalam menjalankan usahanya dan lama nya seorang individu dalam berusaha dapat berdampak pada tingkat literasi keuangan individu tersebut.

UMKM merupakan salah satau usaha home industry produktif yang dilakukan oleh perorangan atau badan usaha dan memiliki bagian langsung dari usaha menengah atau besar yang memiliki modal yang cukup besar dengan omzet sebesar tiga ratus juta Rupiah sampai dengan lima puluh milyar Rupiah per tahun (UU Nomor 20 : 2008). Sesuai dengan riset Bank Indonesia mengungkapkan bahwa sektor UMKM masih mengalami beberpa kendala terutama pada akses permodalan atau keuangan dari lembaga perbankan dan non perbankan sehingga dapat menyebabkan menurunnya jumlah pelaku UMKM dan akan berdampak pada pendapatan meraka. Ketika pendapatan rendah maka rendah pula tingkat literasi keuangan mereka

Berdasarkan teori atribusi Fritz Heider (1958) bahwa jika pelaku UMKM mempunyai tingkat pendapatan usaha lebih tinggi maka individu tersebut maka akan mempunyai kemampuan yang cukup dalam manajemen keuangannya dengan bijak dan di barengi dengan adanya pemahaman manajemen keuangan yang baik pula. Jika seorang individu mempunyai kemampuan pengelolaan keuangannya namun tidak digunakan untuk keperluan usaha maka 
dana tersebut dapat dimanfaatkan untuk memperoleh penghasilan tambahan dalam pemanfaatan produk - produk lembaga keuangan seperti investasi dan asuransi. Selanjtnya artikel Suryanto \& Rasmini (2018); Suryani \& Ramadhan (2017); Arianti (2020); Bushan et al, (2013) mengungkapkan bahwa income berpengaruh pada tingkat literasi keuangan. Berdasarkan hasil penelitian tersebut maka dapat dirumuskan sebuah hipotesis yaitu:

$H_{1}$ : Income memiliki pengaruh signifikan terhadap literasi keuangan

Berdasarkan teori atribusi Fritz Heider (1958) bahwa perilaku seorang individu dapat mempengaruhi pada pengambilan keputusan investasi. Perilaku yang dimaksud disini merupakan perilaku keuangan dalam hal manjemen keuangan yang terlibat di dalamnya. Financial literacy sebagai pengetahuan keuangan individu juga merupakan kebutuhan dasar bagi setiap orang agar terhindar dari permasalahan keuangan. Pengetahuan tentang berinvestasi sangat dibutuhkan oleh pelaku usaha (UMKM) karena dengan berinvestasi tersebut dapat dijadikan sebagai sumber pendapatan tambahan selain dari usaha yang dijalankannya. Ketika seorang individu sudah mulai tergiur dengan investasi namun masih belum cukup memiliki pemahaman dan pengetahuan keuangan dengan baik maka pelaku usaha tersebut akan menjadi korban penipuan investasi bodong. Oleh karena nya diperlukan pemahaman dan pengetahuan keuangan yang tinggi pula. Ningrum (2018) mengungkapkan bahwa adanya pengaruh produk investasi terhadap literasi keuangan. Dari hasil penelitian diatas maka dapat dirumuskan sebuah hipotesis yaitu:

$\mathrm{H}_{2}$ : Investasi memiliki pengaruh signifikan terhadap literasi keuangan

Berdasarkan theory planned behavior, semakin Semakin besar kemudahan dalam mengendalikan perilaku, maka akan semakin baik pula perilaku yang dimiliki oleh individu tersebut yang sedang dipertimbangkan. Yuningsih et al., (2017) mengungkap perilaku keuangan berhubungan dengan tanggung jawab keuangan seseorang terkait dengan cara pengelolaan keuangan. Tanggung jawab keuangan merupakan proses pengelolaan uang dan fase yang dilakukan secara produktif (Yohana, 2010). Sedangkan Susanti et al., (2017) mengungkapkan bahwa seseorang yang memiliki perilaku keuangan yang bertanggung jawab cenderung efektif dalam penggunaan uang yang di miliki seperti membuat anggaran, menghemat uang dan mengontrol belanja, investasi, serta membayar kewajiban tepat waktu. Jadi literasi keuangan yang baik dapat terbentuk dengan adanya perilaku keuangan dan pengetahuan keuangan yang baik. Menurut artikel Arianti (2020) mengungkapkan bahwa variabel perilaku keuangan memiliki pengaruh terhadap literasi keuangan. Dari hasil penelitian diatas maka dapat dirumuskan sebuah hipotesis yaitu:

$H_{3}$ : Perilaku keuangan memiliki pengaruh signifikan terhadap literasi keuangan 
Berdasarkan theory planned behavior mengungkapkan bahwa semakin tinggi pendidikan seorang individu maka semakin tinggi pula pemahaman dan pengetahuan mengenai literasi keuangan dan mayoritas orang yang tinggi pendidikan nya akan memiliki pengetahuan keuangan yang cukup tinggi, selektif dan lebih teliti dalam memilih produk produk keuangan. OJK (2017) mengungkapkan bahwa faktor yang mempengaruhi literasi keuangan adalah tingkat pendidikan, jenis kelamin dan pendapatan. Sedangkan artikel Laxmi \& Maheswary (2018) mengungkapkan bahwa usia, pendidikan, jenis kelamin dan pekerjaan ditemukan sebagai faktor yang cukup berpengaruh literasi keuangan. Bushan et al, (2013) berpendapat bahwa usia tidak berpengaruh pada literasi keuangan namun tingkat pekerjaan, pendidikan, jenis kelamin dan pendapatan memiliki pengaruh literasi keuangan. Das (2016) mengungkapkan bawa pendidikan memiliki pengaruh terhadap literasi keuangan. Dari hasil penelitian diatas maka dapat dirumuskan sebuah hipotesis yaitu:

$H_{4}$ : Tingkat pendidikan berpengaruh signifikan terhadap literasi keuangan

Berdasarkan teori atribusi Fritz Heider (1958) yang menyatakan bahwa seorang individu yang tidak bekerja akan memiliki tingkat literasi keuangan yang rendah karena tidak pernah terlibat dengan isu - isu mengenai keuangan atau seorang individu yang memiliki pengalaman bekerja akan memiliki literasi keuangan yang lebih baik daripada yang tidak mempunyai pengalaman kerja. Lamanya suatu usaha dapat menimbulkan pengalaman berusaha, dimana pengalaman dapat mempengaruhi pengamatan seorang individu dalam berperilaku. Secara tidak langsung lama usaha dapat mempengaruhi pengetahuan seorang individu terhadap bidang usahanya termasuk di dalamnya adalah dalam bidang keuangan. Sesuai dengan artikel Suryani \& Ramadhan (2017) mengungkapkan adanya perbedaan pendidikan yang memiliki pengaruh dengan literasi keuangan. Penelitian ini berbeda dengan artikel Ariani \& Susanti (2015); Irman \& Fadrul (2018) mengungkapkan bahwa pengalaman kerja tidak memiliki pengaruh yang signifikan terhadap literasi keuangan. Irman \& Fadrul (2018) juga mengungkapkan bahwa pengalaman kerja berpengaruh terhadap literasi keuangan. Dari hasil penelitian diatas maka dapat dirumuskan sebuah hipotesis yaitu:

$H_{5}$ : Pengalaman kerja berpengaruh signifikan terhadap literasi keuangan

\section{METODE PENELITIAN}

Pendekatan penelitian ini menggunakan pendekatan kuantitatif dengan metode survey dimana teknik pengumpulan data informasi yang dilakukan menggunakan susunan pernyataan atau pertanyaan yang diajukan kepada responden. Menurut Sugiyono (2016) mengungkapkan bahwa objek penelitian merupakan sasaran ilmiah untuk mendapatkan data dengan tujuan dan 
kegunaan tertentu tentang sesuatu hal objektif, valid, dan reliable tentang suatu hal (variabel tertentu). Subjek penelitian ini yaitu pelaku usaha (UMKM) di Tangerang Selatan dengan sumber data pendukung diperoleh dari Dinas Koperasi dan UMKM kota Tangerang Selatan.

Variabel dalam penelitian terdiri dari variabel terikat adalah literasi keuangan. Untuk mengukur variabel literasi keuangan dan variabel bebas terdiri dari pendapatan, investasi, perilaku keuangan, tingkat pendidikan dan pengalaman kerja diperoleh dengan cara menyebar kuisioner yang berisi pertanyaan atau pernyataan yang terkait dengan faktor yang mempengaruhi literasi keuangan. Jumlah populasi nya sebanyak 23.085 pelaku usaha dikota Tangerang Selatan. Metode sampel yang di gunakan adalah metode simple random sampling memakai rumus slovin dengan tingkat kesalahan 5\% sehingga diperoleh besarnya sampel sebanyak 100 pelaku usaha (UMKM) kota Tangerang Selatan).

Sumber data nya diperoleh dari data primer yang didapatkan dari penyebaran kuesioner kepada responden. Sedangkan data sekunder dapat berupa data dari dinas koperasi dan UMKM kota Tangerang Selatan serta data yang mendukung lainnya berupa media massa, Badan Pusat Statistik, hasil penelitian terdahulu dan buku serta referensi lainnya yang terkait dalam kebutuhan peneliti. Teknik pengumpulan yang di gunakan adalah wawancara, Library Research dan kuesioner.

Metode analisis statistik menggunakan bantuan SPSS versi 25 dengan model regresi linear berganda. Model regresi ini dapat menjelaskan hubungan fungsional antara satu variabel dependen dan lebih dari satu variabel independen. Adapun model persamaan untuk menguji hipotesis secara keseluruhanm dengan persamaan:

$$
\mathrm{Y}=\alpha+\beta_{1} \mathrm{X}_{1}+\beta_{2} \mathrm{X}_{2}+\beta_{3} \mathrm{X}_{3}+\beta_{4} \mathrm{X}_{4}+\beta_{5} \mathrm{X}_{5}+e
$$

Keterangan: $\quad \mathrm{Y}=$ Literasi keuangan

$\alpha=$ Konstanta

$\mathrm{X}_{1}=$ Pendapatan

$\mathrm{X}_{2}=$ Investasi

$\mathrm{X}_{3}=$ Perilaku Keuangan

$\mathrm{X}_{4}=$ Tingkat Pendidikan

$\mathrm{X}_{5}=$ Jenis Kelamin

$\beta_{1}, \beta_{2}, \beta_{3}, \beta_{4}, \beta_{5}=$ Koefisien regresi yang akan dihitung

$e=$ error tolerance

\section{HASIL DAN PEMBAHASAN}


Tabel 2. Hasil Uji t

Coefficients $^{\mathbf{a}}$

\begin{tabular}{|c|c|c|c|c|c|c|}
\hline \multirow{2}{*}{\multicolumn{2}{|c|}{ Model }} & \multicolumn{2}{|c|}{$\begin{array}{c}\text { Unstandardized } \\
\text { Coefficients }\end{array}$} & \multirow{2}{*}{$\begin{array}{c}\text { Standardized } \\
\text { Coefficients } \\
\text { Beta }\end{array}$} & \multirow[t]{2}{*}{$\mathrm{t}$} & \multirow[t]{2}{*}{ Sig. } \\
\hline & & B & Std. Error & & & \\
\hline \multirow[t]{6}{*}{1} & (Constant) & 37,671 & 6,249 & & 6,028 & 0,000 \\
\hline & Pendapatan & 0,422 & 0,172 & 0,227 & 2,455 & 0,016 \\
\hline & Investasi & 0,559 & 0,194 & 0,355 & 2,885 & 0,005 \\
\hline & Perilaku Keuangan & 0,348 & 0,138 & 0,321 & 2,524 & 0,013 \\
\hline & Tingkat Pendidikan & 0,017 & 0,161 & 0,008 & 0,105 & 0,917 \\
\hline & Pengalaman Kerja & $-0,511$ & 0,223 & $-0,204$ & $-2,292$ & 0,024 \\
\hline
\end{tabular}

a. Dependent Variable: Literasi Keuangan

Sumber: data primer, 2020

Berdasarkan uji hipotesis menggunakan SPSS 25.0 didapatkan nilai pendapatan $\left(\mathrm{X}_{1}\right)$ memiliki $t_{\text {hitung }} \geq t_{\text {tabel }}$ yaitu $2,455 \geq 1,984$ dengan nilai signifikansi sebesar $0,016<0,05$. Hal ini dapat diartikan bahwa pendapatan berpengaruh secara positif dan signifikan terhadap literasi keuangan. Determinan dari literasi keuangan seorang individu adalah pendapatan. Pada dasar nya jika tingkat pendapatan tinggi maka semakin mendorong seorang individu dalam penggunaan produk atau dapat dikatakan semakin seseorang bersifat perilaku konsumtif dan di gunakan untuk melakukan pembayaran cicilan kredit (Arianti, 2020). Pendapatan pelaku usaha diukur dengan jumlah pendapatan rata-rata perbulan. Apabila pelaku UMKM mempunyai pendapatan lebih tinggi maka akan mempunyai literasi keuangan yang lebih tinggi pula mungkin seorang individu tersebut mempunyai kemampuan dan pengetahuan untuk merencanakan serta mengontrol keuangannya dengan baik. Penelitian Suryanto \& Rasmini (2018) mengungkapkan bahwa tingkat pendapatan memiliki pengaruh yang positif terhadap literasi keuangan. Pernyataan tersebut yang sesuai juga diungkapkan oleh Arianti (2020) yang mengatakan bahwa faktor pendapatan itu dapat mempengaruhi literasi keuangan. Selanjutnya, menurut penelitian Yusnita \& Abdi (2018); Stolper \& Walter (2017) mengatakan bahwa adanya hubungan positif antara pendapatan individu dengan literasi keuangan.

Hasil pengujian hipotesis menggunakan SPSS 25.0 diperoleh nilai $t_{\text {hitung }}>t_{\text {tabel }}$ yaitu 2,885 > 1,984 dengan nilai signifikansi sebesar 0,005 < 0,05. Hal ini menunjukkan bahwa investasi berpengaruh positif dan signifikansi terhadap literasi keuangan. Salah satu instrumen literasi keuangan yaitu perilaku investasi individu. Oleh karena itu pelaku UMKM sudah mulai sadar akan pentingnya literasi keuangan dan memiliki tingkat pengetahuan yang cukup dalam mengambil keputusan suatu investasi. 
Penelitian Dewi \& Purbawangsa (2018) mengungkapkan bahwa literasi keuangan memiliki pengaruh paling besar dalam menentukan keputusan investasi individu dibandingkan dengan variabel pendapatan dan masa bekerja. Selanjutnya penelitian Viantara, et.al (2019) mengatakan hal yang paling mendasar dalam keputusan investasi adalah return dan risiko. Hal ini menunjukkan bahwa semakin besar laba yang diharapkan, maka semakin besar risiko yang harus dihadapi. Seseorang dapat meminimalisir risiko berinvestasi dan memiliki tingkat literasi keuangan yang cukup dalam proses pengambilan keputusan investasi. Apabila seorang individu memiliki pengetahuan yang tinggi berupa informasi dan sosialisasi mengenai manajemen keuangan pribadinya maka orang tersebut dapat mengambil keputusan dalam pemanfaatan produk - produk keuangan dengan tepat. Pentingnya hal ini merupakan tugas yang besar bagi lembaga keuangan kepada masyarakat serta menjadi tantangan lembaga OJK dalam hal sosiekonomi terutama dalam pendapatan nya.

Selanjutnya uji hipotesis diperoleh nilai thitung > ttabel yaitu 2,524 > 1,984 dengan nilai signifikansi sebesar $0,013<0,05$. Artinya perilaku keuangan berpengaruh positif dan signifikan terhadap literasi keuangan. Hal ini dikarenakan pelaku UMKM mampu menetapkan tujuan keuangan dan membuat perencanaan keuangan baik jangka pendek dan jangka panjang, mampu membuat perencanaan keuangan berasal dari pendapata $\mathrm{n}$ yang diterima dan tidak tergesa-gesa membuat keputusan keuangan. Semakin bagus perilaku keuangan seorang individu maka semakin tinggi literasi keuangan orang tersebut sehingga dapat menetapkan tujuan keuangan dalam menentukan keputusan keuangannya. Penelitian Susanti et al., (2017); Arianti (2020) mengungkapkan bahwa literasi keuangan berpengaruh positif dan signifikan terhadap perilaku keuangan UMKM. Selanjutnya penelitian Rahmayanti et., al (2019) mengungkapkan bahwa perilaku keuangan berpengaruh terhadap literasi keuangan. Jika pelaku usaha memiliki perilaku keuangan yang baik cendrung lebih efektif dan selektif dalam penggunaan uang seperti membuat membuat perencanaan keuangan dan membayar kewajiban tepat waktu.

Hasil pengujian hipotesis menggunakan SPSS 25.0 diatas diperoleh nilai thitung > ttabel yaitu $0,105<1,984$ dengan nilai signifikansi sebesar $0,917>0,05$. Hal ini menunjukkan bahwa tingkat pendidikan berpengaruh positif dan tidak signifikan terhadap literasi keuangan. Kondisi keuangan seorang individu bukan ditentukan oleh seberapa tinggi tingkat pendidikan seseorang atau seorang individu dengan gelar sarjana (S1), master (S2) atau bahkan doctor (S3) belum tentu menjamin kondisi keuangan yang baik. Kondisi keuangan seorang individu lebih ditentukan oleh seberapa besar well literate dan sulficient literate mereka. Tanpa adanya klasifikasi keuangan yang bagus maka akan sulit mencapai 
kondisi keuangan yang baik pula dan bahkan menjadikan mereka rentan terhadap penyalahgunaan produk dan jasa keuangan (OJK, 2017). Maka dari itu sebaiknya pihak OJK dan lembaga pendidikan seharus nya memberikan atau melakukan sosialisasi dan edukasi literasi keuangan yang merata ke seluruh indonesia walaupun lembaga OJK sudah membuat buku beberapa buku mengenai literasi keuangan namun masih sulit di dapatkan karena dianggap ridak merata. Dengan adanya buku tersebut maka akan meningkatkan pemahaman ilmu keuangan baik dari seluruh sasaran lembaga OJK termasuk pelajar, akademisi, ibu PKK, maupun pengusaha. Di samping itu pula pihak OJK juga berencana akan mengadakan seminar/workshop untuk bedah buku/edukasi literasi keuangan bagi pelaku UMKM supaya mereka lebih mendalami pemahaman tentang pentingnya literasi keuangan bagi seorang individu, terutama pelaku usaha. Penelitian ini sejalan dengan penelitian yang dilakukan oleh Yusnita \& Abdi (2018) mengatakan bahwa tingkat pendapatan dan pendidikan berpengaruh terhadap literasi keuangan. Selanjutnya berbeda dengan artikel Hidayati \& Anwar (2018) mengungkapkan bahwa tingkat pendidikan tidak mempengaruhi literasi keuangan dan menggambarkan hubungan yang negatif. Hal ini bukan berarti lembaga pendidikan tidak mengajari ilmu tentang keuangan dengan baik tetapi bukan pada sepenuhnya mempelajari literasi keuangan, maka pelaku usaha itu harus mencari ilmu tambahan mengenai ilmu keuangan atau literasi keuangan supaya kedepannya mereka lebih bertambah pemahaman dan pengetahuan dalam memajemen keuangan pribadinya ataupun keuangan usaha bisnis.

Hasil pengujian hipotesis menggunakan SPSS 25.0 diperoleh nilai thitung > tabel yaitu $-2,292<1,984$ dengan nilai signifikansi sebesar $0,024<0,05$. Artinya pengalaman kerja berpengaruh negatif dan secara signifikan terhadap literasi keuangan. Ini menunjukan bahwa pelaku UMKM yang sudah lama memiliki usaha dan meempunyai pengalaman kerja yang cukup maka akan memiliki tingkat literasi keuangan yang lebih tinggi jika dibandingkan dengan pelaku UMKM yang baru terdaftar untuk memiliki usaha ataupun belum memiliki pengalaman kerja sama sekali dalam dunia bisnis. Pengujian ini sesuai dengan penelitian Irman \& Fadrul (2018); Nurhidayati \& Anwar (2018); menunjukkan bahwa pengalaman kerja berpengaruh terhadap tingkat literasi keuangan. Semakin lama pelaku UMKM memiliki usaha maka literasi keuangan juga semakin tinggi. Jadi, pelaku UMKM yang mempunyai pengalaman kerja cukup maka semakin banyak pengetahuan keuangan dari lingkungan kerja nya yang sudah familiar dengan produk - produk keuangan yang di tawarkan oleh lembaga keuangan.

Hasil pengujian hipotesis menggunakan SPSS 25.0 diperoleh $F_{\text {hitung }}>F_{\text {tabel }}$ yaitu $18,423>2.31$, dan nilai signifikansi $0,000<0,05$ maka dapat disimpulkan bahwa hipotesis ke 
enam terdapat pengaruh secara simultan pendapatan, investasi, perilaku keuangan, tingkat pendidikan dan pengalaman kerja terhadap tingkat literasi keuangan. Hasil penelitian ini menunjukkan bahwa faktor demografi dan sosio ekonomi sangat penting dalam membentuk literasi keuangan. Faktor demografi sosio ekonomi dapat menggambarkan kondisi dan perubahan masyarakat. Semakin tinggi tingkat pendapatan, perilaku keuangan, berinvestasi, tingkat pendidikan dan pengalaman kerja pelaku usaha maka semakin tinggi pula literasi keuangan dalam manajemen keuangan nya.

\section{KESIMPULAN}

Penelitian ini dapat memberikan kesimpulan bahwa pertama, pendapatan berpengaruh secara positif dan signifikan terhadap literasi keuangan. Kedua, investasi berpengaruh positif dan signifikan terhadap literasi keuangan. Ketiga, perilaku keuangan berpengaruh positif dan signifikan terhadap literasi keuangan. Keempat, tingkat pendidikan berpengaruh positif dan tidak signifikan terhadap literasi keuangan. Kelima, pengalamn kerja berpengaruh negatif dan secara signifikan terhadap literasi keuangan. Selanjutnya, terakhir terdapat pengaruh secara simultan pendapatan, investasi, perilaku keuangan, pendidikan dan pengalaman kerja pada tingkat literasi keuangan.

Berdasarkan kesimpulan dan hasil penelitian yang telah dikemukakan diatas, maka saran-saran sekaligus rekomendasi yang diajukan kepada pihak pelaku UMKM di Kota Tangerang Selatan akan lebih baik jika dapat meningkatkan literasi keuangan dengan tingkat pengetahuan keuangan yang dimiliki agar dapat mengelola keuangan usaha yang dijalankan dengan baik dan efisien serta memiliki keunggulan dalam persaingan global. Disamping itu juga pelaku UMKM harus lebih proaktif dalam mencari tahu mengenai informasi terkait produk dan layanan jasa keuangan agar dapat mempermudah dan pemanfaatan akses lembaga jasa keuangan melalui digital atau internet.

Bagi pemerintah kota Tangerang Selatan, bahwa diharapkan pihak pemerintah khususnya dinas koperasi dan UMKM dikota Tangerang Selatan sebaiknya harus lebih aktif dan secara merata dalam melakukan sosialisasi serta edukasi literasi keuangan kemudian memperluas dan mempermudah akses masyarakat serta pengembangan layanan keuangan digital atau internet melalui kerjasama dengan pihak OJK dan lembaga keuangan perbankan dan non perbankan. Kemudian pemerintah di harapkan melakukan kegiatan pelatihan dan workshop ataupun pendampingan terkait literasi keuangan yang akan sangat membantu dalam meningkatkan pengetahuan dan kemampuan pengelolaan keuangan kepada pelaku usaha. 


\section{REFERENSI}

Ajzen, I. (1991). The Theory of Planned Behavior. Organizational Behavior and Human Decision Processes, $50: 179-211$

Ariani, N. A. dan S. (2015). Pengaruh Faktor Demografi terhadap Financial Literacy Mahasiswa Fakultas Ekonomi Universitas Negeri Surabaya Angkatan 2012. Jurnal Pendidikan Akuntansi (JPAK), 3 (2), 11. http://jurnalmahasiswa.unesa.ac.id

Arianti, B. F. (2020). Pengaruh Pendapatan dan Perilaku Keuangan terhadap Literasi Keuangan melalui Keputusan Berinvestasi sebagai Variabel Intervening. Jurnal Akuntansi, 10(1), 13-36. https://doi.org/10.33369/j.akuntansi.10.1.13-36

Aribawa, D., (2016). Pengaruh Literasi Keuangan terhadap Kinerja dan Keberlangsungan UMKM di Jawa Tengah. Jurnal Siasat Bisnis, 20(1), 1 - 13

Anggraeni, B. D. (2015). Pengaruh Tingkat Literasi Keuangan Pemilik Usaha. Jurnal Vokasi Indonesia, 3(2), 109-121.

Bhushan, P., \& Medury, Y. (2013). Financial Literacy and its Determinants. International Association of Scientific Innovation and Research, 4(2), 155-160.

Das, S. (2016). Financial Literacy: Measurement and Determinants. EPRA International Journal of Economic and Business Review, 509(June), 88-93. http://eprawisdom.com/jpanel/upload/articles/104pm11.Sanjib.pdf

Fatmawati M. Lumintang. (2013). Jurnal EMBA. Jurnal EMBA, 2(3), 1768-1780.

Heider, F. (1958) The Psychology of Interpersonal Relations. New York: John Wiley \& Sons. http://dx.doi.org/10.1037/10628-000

Humaira, I., \& Sagoro, E. M. (2018). Pengaruh Pengetahuan Keuangan, Sikap Keuangan, dan Kepribadian terhadap Perilaku Manajemen Keuangan pada Pelaku UMKM Sentra Kerajinan Batik Kabupaten Bantul. Nominal, Barometer Riset Akuntansi Dan Manajemen, 7(1). https://doi.org/10.21831/nominal.v7i1.19363

Irman, M., \& Fadrul, F. (2018). Analisis Pengaruh Jenis Kelamin, IPK, dan Pengalaman Kerja terhadap Tingkat Financial Literacy. Journal of Economic, Bussines and Accounting (COSTING), 2(1), 41-56. https://doi.org/10.31539/costing.v2i1.345

Laxmi, V., \& Maheshwary, N. K. (2018). Identification of Factors Influencing Financial Literacy: A Theoretical Review. International Journal of Research in Management, Economics and Commerce, 08(1), 89-94.

Mahdzan, N. S., \& Tabiani, S. (2013). The Impact of Financial Literacy on Individual Saving: an Exploratory Study in The Malaysian Context. Transformations in Business and Economics, 12(1), 41-55.

Mertha Dewi, I., \& Purbawangsa, I. B. A. (2018). Pengaruh Literasi Keuangan, Pendapatan Serta Masa Bekerja terhadap Perilaku Keputusan Investasi. E-Jurnal Ekonomi Dan Bisnis Universitas Udayana, 7, 1867. https://doi.org/10.24843/eeb.2018.v07.i07.p04

Ningrum, Asrowati, I. (2018). Analisis Faktor Pengaruh Literasi Keuangan terhadap Pelaku UMKM Kota Makasar. Fakultas Ekonomi Universitas Islam Indonesia, Yogyakarta

Nurhidayati, S., \& Anwar, M. (2018). Pengaruh Faktor Demografi terhadap Literasi Keuangan Syariah Karyawan Perbankan Syariah di Surabaya. Jurnal Ekonomi Islam, $1(1), 1-11$.

OJK. (2017). Strategi Nasional Literasi Keuangan Indonesia (Revisit 2017). Otoritas Jasa Keuangan, 1-99.

Ponio, J. C., \& Timog, R. C. (2017). Financial Knowledge, Behavior and Attitude of Micro Business Owners: Basis for Developing Financial Literacy Training Modules. International Journal of Management and Applied Science, 3, 2394-7926. http://iraj.in

Rahmayanti, W. (2019). Pengaruh Sikap Keuangan dan Perilaku Keuangan terhadap Literasi Keuangan (Studi Kasus pada Ibu Rumah Tangga di Desa Lito Kecamatan Moyo Hulu ). Jurnal Manajemen Dan Bisnis, 2(1), 9. http://jurnal.uts.ac.id 
Remund, D. L. (2010). Financial Literacy Explicated: The Case For a Clearer Definition in an Increasingly Complex Economy. Journal of Consumer Affairs, 44(2), 276-295. https://doi.org/10.1111/j.1745-6606.2010.01169.x

Stolper, O. A., \& Walter, A. (2017). Financial Literacy, Financial Advice, and financial Behavior. Journal of Business Economics, 87(5), 581-643. https://doi.org/10.1007/s11573017-0853-9

Suryanto, S., \& Rasmini, M. (2018). Analisis Literasi Keuangan dan Faktor-Faktor yang Mempengaruhinya. Jurnal Ilmu Politik dan Komunikasi, 8(2). https://doi.org/10.34010/jipsi.v8i2.1336

Suryani, S., \& Ramadhan, S. (2017). Analisis Literasi Keuangan pada Pelaku Usaha Mikro di Kota Pekanbaru. Journal of Economic, Business and Accouting (COSTING), 1(1), 12 22

Susanti, A. (2017). Tingkat Pendidikan, Literasi Keuangan, Dan. Telaah Bisnis, 18(1), 45-56.

Viantara, A., Worang, F. G., Tumewu, F. J., Universitas, D. I., Ratulangi, S. A. M., \& Tumewu, F. J. (2019). Effect of Financial Literacy on Investment Decision (Study Case on Students of Faculty of Economy and Business At Sam Ratulangi University). Jurnal EMBA: Jurnal Riset Ekonomi, Manajemen, Bisnis Dan Akuntansi, 7(4), 4777-4786. https://doi.org/10.35794/emba.v7i4.25428

Yuningsih, I., Andreieta Shintia D., \& Tieka Trikartika G. (2017). Analisis Literasi Keuangan di Masyarakat Kota Bandung. Dewan Penyunting. Poros, 15(2). https://doi.org/10.24912/poros.v15i2.1262

Yohana, I. (2010). Pengaruh Locus of Control, Financial Knowledge, Income terhadap Financial Management Behavior. Jurnal Bisnis Dan Akuntansi, 12(3), 131-144.

Yusnita Ria, R. \& Abdi, M. (2018). Pengaruh Faktor Demografi terhadap Literasi Keuangan. Journal Of Economic, Business and Accouting (COSTING), 2(1), 163 - 184 